\title{
INTERFERON AND ITS FIRST CLINICAL TRIAL: LOOKING BEHIND THE SCENES
}

\author{
by
}

\author{
TOINE PIETERS *
}

On the morning of 25 March 1980, there was unusual activity at Glasgow airport's Customs. A parcel containing a bottle of the most valuable drug in the world, interferon, had just arrived from Denmark. Hailed as a possible cure for cancer, interferon was intended for the experimental treatment of two young patients with advanced cancer at the Royal Hospital for Sick Children in Glasgow. ' The event stirred widespread attention in the British press in the late seventies and early eighties, and was part of a global media hype of interferon's promise as a "magic bullet" against cancer. ${ }^{2}$ Some typical headlines were: "The drug with a value beyond price". and "The miracle cure of the future?". 4 The euphoria surrounding interferon faded when it appeared that the drug's performance in large-scale cancer trials had been disappointing, and that it often produced severe side effects in patients. $^{5}$

Interferon had hit the headlines for the first time in Britain about twenty years earlier. In May 1958, Alick Isaacs, a virus researcher at the National Institute of Medical Research (NIMR), Mill Hill, London, announced the finding of an inhibitor of virus growth, named interferon. Subsequently, the press reported the discovery of a substance which might one day play an important part in the fight against viruses, a potential new "antiviral penicillin". This possibility was an important incentive for the immediate start of negotiations between the Medical Research Council (MRC), which was responsible for NIMR's activities, and a

\footnotetext{
* Toine Pieters, University of Limburg, FdAW, Department of Philosophy, P.O. Box 616, 6200 MD Maastricht, The Netherlands.

A preliminary version of parts of this paper was presented to the Twentieth Century Medical History Group of the Wellcome Trust at the Royal College of Physicians. I have benefited enormously from the discussion following that lecture. Furthermore I am deeply indebted to Dr Wiebe, E. Bijker, Dr Harmke Kamminga, Dr Annemarie Mol, Roel Otten, Dr Roy Porter, Dr Joke Spruyt, Dr Reinder Vos and two anonymous referees for their comments and criticisms. A part of this research was supported by a grant from the Wellcome Trust. I am also grateful to the Medical Research Council, in particular Mrs Mary Nicholas, and all those scientists who provided me with the necessary archival material.
}

\footnotetext{
' Stephanie Yanchinski, 'What next for interferon?', New Scientist, 25 September 1980, 917-21; Michael Edelhart and Jean Lindenmann, Interferon: Wondermiddel of hersenschim?, Utrecht, Veen Publishers, 1982, pp. 9-10.

${ }^{2}$ Sandra Panem, The interferon crusade, Washington D.C., The Brookings Institution, 1984.

3 'The drug with a value beyond price', Weekly News, Britain, 8 December, 1979.

4 'The miracle cure of the future?', Financial Weekly, Britain, 25 July, 1980.

5 T. B. Powledge, 'Interferon on trial', Biotechnology, March 1984, pp. 214-28. Despite the negative press interferon got in the early eighties, it succeeded in finding a niche in clinical practice by the mid-eighties as a drug against a small number of virus diseases, e.g., papilloma, and certain cancers, e.g., hairy cell leukaemia.
} 
number of major British drug companies. The MRC did not have the resources and expertise to develop interferon as an antiviral drug and therefore sought collaboration with industry. During the war a consortium of British pharmaceutical companies, incorporated as the Therapeutic Research Corporation, had collaborated on a penicillin development programme, but there did not exist a peacetime model for such a collaboration. Hence, the National Defense Research Development Corporation was entrusted with the task of making proposals for an agreement between the MRC and a selection of British drug companies.

In order to develop and carry out a collaborative research programme, a Scientific Committee on interferon was set up under the chairmanship of Isaacs. In the course of 1960 , the scientific committee gave the go-ahead to prepare experiments with interferon on humans. In the first such experiment, which was carried out during January 1962, the effect of interferon on vaccination was tested on volunteers. Shortly afterwards, on 28 April 1962 a report of this trial was published in the Lancet which maintained that the clinical trial with interferon was based on unambiguous experiments with an antiviral substance in, successively, the test-tube (in vitro) and laboratory animals (in vivo). The transition between in vitro and in vivo tests, and tests on humans was depicted as unproblematic. In addition, the experiment was said to show that interferon had an antiviral effect in man.

In retracing interferon's origin and developments up to the 1962 trial, I focus attention on two issues. First, the contingencies and uncertainties faced during laboratory and clinical practice are elucidated. In general there are erased from published scientific papers like the Lancet report. Thus, I show that the transition between in vitro and in vivo tests, and tests on humans was far from unproblematic, thereby demonstrating that self-evidence in biomedical experiments and experimental transitions is a scientific myth. Second, some aspects of the first successful postwar initiative to secure a collaboration between the British government and the drug industry are highlighted.

\title{
THE LANCET REPORT
}

\begin{abstract}
EFFECT OF INTERFERON ON VACCINATION IN VOLUNTEERS
A Report to the Medical Research Council from the Scientific Committee on Interferon

Interferon is known to be produced in the course of many virus infections both in vitro and in animals, and it is thought to play a role in recovery from viral infections. It therefore seemed possible that it might one day find a use in the treatment of virus infections in man and animals. In exploring this possibility we have carried out a first experiment to see whether interferon prepared in the laboratory could prevent the establishment of a virus infection in man. ${ }^{6}$
\end{abstract}

These are the opening lines of an article in the Lancet, 28 April 1962. Subsequently, the reader is informed about the production of both interferon and a control fluid without interferon, the assays of interferon, the safety tests, and finally about the conduct of the trial. The safety tests were carried out both during and at the end of the production process. During it, the researchers tested for the presence of viruses and bacteria; samples of the final

${ }^{6}$ Scientific Committee on Interferon, 'Effect of interferon on vaccination in volunteers', Lancet, 1962, i: 873-5, p. 873. 


\section{Toine Pieters}

product were taken for toxicity tests in mice and guinea-pigs; and, as a final test, the interferon, as well as the control fluid, was inoculated into the forearm of volunteers. Apart from a single case of swelling, no side effects were registered.

The trial was performed as follows. The interferon preparation and a control preparation without interferon, which looked alike, were coded according to a random list of coding letters and were distributed "blind" together with vaccine by the MRC's immunological products control laboratory in Hampstead. Subsequently, all the participating laboratories recruited volunteers who each received two injections with either interferon or the control fluid in one arm, $5 \mathrm{~cm}$ apart. The next day they were given vaccinations against smallpox at the same arm sites. For a fortnight afterwards, frequent readings of both arm spots were made and any lesions that developed were measured and noted. The observer and the vaccinator were different people so as to ensure that the observer would read the vaccine takes "blind". Thus the test procedure was a "double blind". Finally, the volunteer records were returned to the distribution laboratory, where the codes had been kept. The results prompted the following conclusion:

Definite evidence of protection by interferon was found and since the trials were carried out blind it is clear that the protective effects can be accepted as unbiased results. ${ }^{7}$

In addition to this conclusion, the report added a discussion of both the trial and its results:

The present trial was based on experiments in animals where it had been shown that interferon could prevent the development of a vaccinial lesion in the skin of the rabbit and of the monkey. Monkey interferon was known to inhibit virus growth in human cells in vitro and it was therefore used in this trial. ${ }^{8}$

To put it briefly, according to the report, the clinical trial with interferon was carried out as a result of unambiguous experiments with an antiviral substance in the laboratory. The transition from experiments in the test-tube and in laboratory animals to experiments with humans was depicted as unproblematic. In addition, the trial was said to have proceeded smoothly and unmistakably showed that interferon had an antiviral effect in man.

Recent studies in the history and sociology of science which have examined the path from laboratory to published scientific paper have convincingly shown that scientific communications to learned journals have to be regarded as retrospective experimental narratives, which comply with stereotyped formats and do not accurately represent the research work made public. ${ }^{9}$ Published scientific accounts are reconstructions rather than records of the actual investigative pathway, and by reconstructing the research process into

\footnotetext{
${ }^{7}$ Ibid., pp. 874-5.

${ }^{8}$ Ibid., p. 875.

${ }^{9}$ For studies on the reconstructive nature of published scientific accounts see, Karin Knorr-Cetina, The manufacture of knowledge: an essay on the constructivist and contextual nature of science, Oxford, Pergamon Press, 1981; Michael Callon, John Law and Arie Rip, Texts and their powers: mapping the dynamics of science and technology, London, Macmillan, 1986; Bruno Latour and Steve Woolgar, Laboratory life: the construction of scientific facts, Princeton University Press, 1986; F. L. Holmes, 'Scientific writing and scientific discovery', Isis, 1987, 78: 220-35; David Gooding, Experiment and the making of meaning, Science and Philosophy, vol. 5, Dordrecht, Kluwer Academic Publishers, 1990, p. 6; Peter Medawar, 'Is the scientific paper a fraud?', in D. Pyke (ed.), The thread and the glory: reflections on science and scientists, Oxford University Press, 1991, pp. 228-33.
} 


\section{Interferon and its first clinical trial}

a linear order of experimental narratives, procedures and choices are rendered invisible. In addition, printed public records lack the contingencies and uncertainties which scientists constantly face during their work and the subsequent management (negotiation) of uncertainty. Despite the fact that these studies have pointed out, and to some degree analysed the process of the deletion of uncertainty from scientific texts, this deletion process has only occasionally been described with reference to the details of laboratory and clinical practice. The same is true for the varieties of uncertainties faced by scientists. ${ }^{10}$ In the case of the Lancet report this invites the following questions. How unambiguous were the experiments which preceded the interferon trial? Are the transitions between experiments in vitro and in vivo and on humans as self-evident as the report would have us believe? Or, in broader terms, what kind of uncertainties lie hidden behind the "Lancet screen" of objective, rule-bound science? In order to recover contingencies and uncertainties which have been deleted from the public record and answer these questions, I will retrace interferon's origin and development up to the vaccination trial on the basis of minutes, interviews, personal notes and correspondence. Moreover, the reconsideration of the early history of interferon research will highlight some aspects of the first successful postwar initiative to set up a collaboration between the British government and the drug industry.

\section{RETRACING INTERFERON'S ORIGIN}

Early in 1957, in one of the laboratories of the NIMR, Alick Isaacs completed a series of two articles for the Proceedings of the Royal Society. Together with Jean Lindenmann, a Swiss virologist, he claimed to have found a new biological factor during a study of the interference phenomenon. This biological phenomenon had first been named by the British scientists Gerald Findlay and Frank MacCallum in 1937. ${ }^{11}$ Findlay and MacCallum had observed that infection with Rift Valley fever virus protected monkeys from infection with the unrelated yellow fever virus. Their phenomenon was defined as the interference of one virus with the pathogenic action of another, hence the name "interference phenomenon". ${ }^{2}$ The interference phenomenon had been studied most extensively in the developing chicken egg, ever since in the 1940s, the American virologists Werner and Gertrude Henle had shown that the interference phenomenon could be studied most conveniently in that test system, free from many of the complicating factors in laboratory animals. These often became cross-infected, carried undetected virus infections, and were argued to have more complicated defence reactions, which intervened to confuse the experimental data. Moreover, as an experimental system, the chicken egg was easier to manipulate and more economical. Initially there had been discussions concerning the extent to which the results obtained in the chicken egg had a bearing on the interference phenomena in laboratory

\footnotetext{
10 Susan Lee Star has been the first to point out the neglect of the role and the varieties of uncertainty in laboratory and clinical practice in: Regions of the mind: brain research and the quest for scientific certainty, Stanford University Press, 1989, pp. 64-5.

"In retrospect one may find earlier observations concerning inhibition phenomena between viruses, both in animals and plants. These observations go back even to the pre-bacteriologic era: see W. Henle, 'Interference phenomena between animal viruses: a review', J. Immun., 1950, 64: 203-35, p. 205. For instance, in 1804 the famous British doctor Jenner reported in a letter to the editors of the Medical and Physical Journal observations which led him to believe that "herpetic affections often prevented the vaccine virus from producing its correct action", E. Jenner, letter to the Editor, Med. and Phys. J., 1804, 12: 97-102, p. 97.

12 G. M. Findlay and F. O. MacCallum, 'An interference phenomenon in relation to yellow fever and other viruses', J. Path. and Bact., 1937, 44: 405-24, p. 420.
} 


\section{Toine Pieters}

animals, but, as the use of the chicken egg spread, the uncertainty regarding this experimental transition faded into the background. ${ }^{13}$

Isaacs was in charge of the laboratory of the World Influenza Centre, which was part of the NIMR's division of Bacteriology and Virus Research, and had been set up in collaboration with the World Health Organisation (WHO) as the centre of a global network of collaborating laboratories to study influenza viruses. These were held responsible for the outbreak of various flu epidemics throughout the world. Inside the World Influenza Centre all sorts of data concerning flu epidemics were accumulated, together with virus specimens, in order to elucidate the epidemiology and nature of influenza viruses, and, ultimately, to control the outbreak of flu epidemics. ${ }^{14}$ In the early fifties, Isaacs had studied extensively the interference phenomenon between the inactivated influenza virus (which had been rendered non-infective by heat) and the live influenza virus in the developing egg. In these studies he had ascribed the interference phenomenon, which by then was characterized as the inhibitory effect of one virus upon the propagation of another, to the competition between an interfering (inactivated) and a challenging (live) virus for some keyconstituent within the cell. Lindenmann, a visiting research worker from the Institute of Microbiology of the University of Zürich, had been involved in experiments with influenza virus in the chicken egg showing that heat-inactivated virus interfered with the growth of live virus even when stuck to the surface of red blood cells.

Sometime in August 1956 Lindenmann was introduced to Isaacs and told him about his observation that inactivated influenza virus attached to red blood cells was a good interfering agent. To the best of Lindenmann's memory, Isaacs showed an enthusiastic interest and suggested two possible explanations for this finding. The virus could have become detached from the red blood cells during the experiment and induced interference by entering the cell as a whole, or the virus coat (virus haemagglutinin) might have remained firmly attached to the red cells, while only the virus content (virus nucleic acid) had entered the cell and induced interference. This latter assumption was prompted by the idea that in analogy with bacterial viruses (bacteriophages), ${ }^{15}$ during infection with influenza virus only the virus nucleic acid entered the host cell, while the virus coat remained outside. Lindenmann's experiment seemed to offer a unique opportunity to test Isaacs' assumption. Isaacs then asked Lindenmann whether he would like to work on influenza viruses and, if possible, test the "nucleic acid hypothesis". ${ }^{16}$

\footnotetext{
${ }^{13}$ Henle, op. cit., note 11 above, pp. 216-18; Sally Smith Hughes, The virus: a history of the concept, London and New York, Heinemann Educational Books, Science History Publications, 1977, p. 93; W. Schlessinger, 'Interference between animal viruses', in F. M. Burnet and W. M. Stanley (ed.), The viruses, New York, Academic Press, 1959, pp. 157-94.

${ }^{14}$ C. Andrewes, 'Alick Isaacs', Biographical Memoirs of Fellows of the Royal Society, 1967, 13: $205-32$.

15 Probably this was prompted by new developments in the field of virology. In 1952, Alfred Hershey and Martha Chase had shown that during bacterial virus infection only the virus content entered the cell, while the protein coat remained at the surface. They believed the virus nucleic acid to be directing the viral reproduction. By 1956 , within the field of virology consensus had emerged over the study of bacterial viruses as a simple model for virus multiplication and a possible key to the elucidation of virus-host systems; it was fashionable to think that animal virus infections proceeded in a similar way to bacterial virus infections. See, T. van Helvoort, 'History of virus research in the 20th century: the problem of conceptual continuity', forthcoming in History of Science; Jean Lindenmann, interview, Zürich, 11-15 June 1990.

${ }^{16}$ A. Isaacs, 'Viral interference', Symp. Soc. Gen. Microbiol., 1959, No. 9, 102-21, p. 108; J. Lindenmann, 'Neuere Aspekte de Virus-Interferenz', Z. Hyg. Infektionskrankh., 1960, 146: 369-97, p. 383; J. Lindenmann, 'Induction of chick interferon: procedures of the original experiments', Methods in Enzymology, 1981, 78:
} 


\section{Interferon and its first clinical trial}

Isaacs' notebook has an entry for 4 September 1956 where he says that he and Lindenmann started with an experiment to see if virus-coated red blood cells could induce interference in the test-tube. ${ }^{17}$ Technically, this first collaborative experiment differed substantially from Lindenmann's original interference experiment. First, Isaacs decided that instead of doing the experiment in chicken eggs, they would try a novel system for influenza virus multiplication. This new experimental model had been applied successfully in a number of viral interference experiments by his friend David Tyrrell and was said to be much more convenient and easier to manipulate. ${ }^{18}$ The chicken embryo membrane from the whole egg was removed and cut into pieces. Five eggs produced about thirty pieces of membrane. These small pieces of tissue were then washed in a dish and added, one at a time, to a test-tube filled with a special nutrient fluid. This could be done very fast and by a laboratory technician. Subsequently, the virus or the controls were injected into the test-tubes and these rolled overnight in so-called roller drums. The next day the fluid could be taken out of the tubes and the amount of virus quantified. ${ }^{19}$ This new experimental procedure required roughly one-sixth of the usual amount of fertilized eggs, thus saving both money and space. In addition, experiments on the whole egg required far more skill and time than the manipulations with the pieces of membrane in the test-tube. Further, it was argued that the in vitro system could be more readily quantified and manipulated.

A second difference from the original experiment was to stick the interfering (heat-inactivated) virus to haemolysed red blood cells, ${ }^{20}$ so-called red cell ghosts, instead of normal blood cells. By attaching the virus to red cell ghosts, Isaacs and a worker from the biophysics and optics department had managed some years before to visualize influenza virus particles. ${ }^{21}$ They had made a series of electron micrographs with the electron microscope, showing red cell ghosts with distinctive round structures on them, which were said to represent virus particles. Isaacs hoped that by sticking the interfering virus to red cell ghosts it would be possible to obtain similar clear pictures of the virus-coated red cell ghosts in his experiment with Lindenmann. If, as Isaacs assumed, during interference only the virus nucleic acid ${ }^{22}$ entered the host cell, while the virus coat remained firmly attached to the red cell ghosts, they would be able to see full round virus structures before, and collapsed structures after the interference had taken place. Furthermore, Isaacs decided that

181-8, p. 182; J. Lindenmann, 'From interference to interferon: a brief historical introduction', Phil. Trans. $R$. Soc. Lond., 299: 3-6, p. 3.

${ }^{17}$ A. Isaacs, Laboratory Notebooks, 1946-65, National Library of Medicine (Bethesda), Film number: reel 91-28, Lab Note Book, S.O. Book 135, Code 28-72-0, 'Alick Isaacs Interference Expts. V', 4 September 1956.

${ }^{18}$ Lindenmann interview, see note 15 above; D. Tyrrell and I. Tamm, 'Prevention of virus interference by 2,5-Dimethylbenzimidazole', J. Immun., 1955, 75: 43-9, p. 43; David Tyrrell, interview, Salisbury, 21 May 1990.

${ }^{19}$ An indication of the amount of virus in a test-tube fluid could be obtained by making a series of dilutions of the fluid and adding a constant volume of fowl red blood cells to each dilution. Since red blood cells had been shown to agglutinate proportionally to the number of virus particles present, it was agreed by convention that the highest dilution at which complete agglutination occurred was taken as a measure for the virus concentration in a fluid. See, A. Isaacs, 'Laboratory methods used in investigating influenza', Glasg. med. J., 1948, 29: 357-61, p. 359.

20 The plasma membrane of these cells had been ruptured by chemical treatment and consequently these red blood cells had lost their haemoglobin content (pigment).

${ }^{21}$ H. Donald and A. Isaacs, 'Counts of influenza virus particles', J. gen. Microbiol., 1954, 10: 457-64, p. 459.

22 The nucleic acid could be either DNA or RNA and was present in the virus envelope. Three years after James Watson and Francis Crick had proposed the double helix model for DNA structure and function, the nucleic acid content of the virus had been shown to be the infective component and to play a vital role in viral replication, see Hughes op. cit., note 13 above, p. 101. 


\section{Toine Pieters}

they would use the same strain of influenza and the same method of viral inactivation that he had used successfully in previous interference experiments. Thus, for the greater part, their initial experimental set-up consisted of materials and techniques which had either been employed by Isaacs and Lindenmann in earlier experiments, or circulated in the local context of the division of Bacteriology and Virus Research. ${ }^{23}$

Standing face to face at the bench in Isaacs' laboratory, Lindenmann, Isaacs and a laboratory technician began by cutting and washing the chicken embryo membranes, heat inactivating batches of influenza virus, preparing red cell ghosts, and sticking part of the inactivated virus to these ghosts. After this preparatory work, they did a first experiment to see whether or not they could induce viral interference in their test-tubes. Pieces of membrane were put one by one into the test-tubes together with nutrient fluid and either virus stuck to red cell ghosts, free inactivated virus, or no virus. The latter was referred to as the control preparation. After twenty-four hours in a roller-drum the test-tube fluids were replaced by fresh solutions containing live virus and rolled anew. Half way through the first week, the amount of virus in each test-tube was quantified and the experimental results were written down in Isaacs' notebook. The results were encouraging and showed that both free virus and virus stuck to red cell ghosts were able to inhibit the growth of live virus in this "test-tube arrangement". ${ }^{24}$ Subsequently, they played around with their experimental arrangement in order to set the optimal experimental conditions for producing interference in the test-tube.

On 25 September a first attempt was made to visualize ghosts and virus particles in the test-tube fluid with the help of the electron microscope. Samples were taken at the start of the interference experiment and halfway through it, just before the test-tube fluids were discarded and replaced by fresh solutions and the live virus was added. By special request Robert Valentine, a researcher from the biophysics and optics department, immediately processed electron microscopic images of these samples from Isaacs' laboratory. The pictures of the first sample, taken at the start of the experiment, looked promising. Clearly visible structures of red cell ghosts with virus particles attached to them could be distinguished, and Isaacs showed Lindenmann that it was even possible to count the number of particles per ghost. But the photographs taken after the test-tubes had been rolled for a time were disappointing. The ghosts looked rather dirty and the electron micrographs were hard to interpret. They could not tell the difference in structure between virus particles in samples taken before and after the interference experiment, nor was it possible to tell whether in an additional control sample without membranes, which contained a mixture of virus-coated ghosts and empty ghosts, virus particles had become unstuck and transferred to the empty ghosts. In Isaacs' notebook two question marks serve to highlight the problems of interpreting these electron microscopic images. ${ }^{25}$ Despite subsequent attempts to refine the

\footnotetext{
${ }^{2.3}$ Alick Isaacs to Herman Mooser, letter dated 18 November 1957, Jean Lindenmann to Herman Mooser, letter dated 7 August 1958, Jean Lindenmann to Herman Mooser, letter dated 13 August 1958, all in Jean Lindenmann Correspondence, personal archives, Zürich; J. Lindenmann, 'Induction of chick interferon: procedures of the original experiments', Methods in Enzymology, 78: 181-8, pp. 182-3; J. Lindenmann, 'From interference to interferon: a brief historical introduction', Phil. Trans. R. Soc. Lond., 1982, series B, 299: 3-5, pp. 3-4; Lindenmann interview, see note 15 above.

${ }^{24}$ Donald and Isaacs, op. cit., note 21 above; Lindenmann interview, see note 15 above.

${ }^{25}$ Isaacs, op. cit., note 17 above, 25 September 1956; for a detailed account of the original experiments see Lindenmann, op. cit., note 23 above, pp. 181-8.
} 
experimental procedures, Valentine did not succeed in producing much better images of ghosts, though there were hints that in the mixture of virus-coated ghosts and empty ghosts a transfer of virus particles from one to the other had taken place. ${ }^{26}$

According to Lindenmann, "at a certain moment in November 1956, after about two months of experimentation, Isaacs felt that something unusual was happening while re-using the test-tube fluid with inactivated influenza virus in a second interference experiment." ${ }^{27}$ Contrary to Isaacs' expectation, ${ }^{28}$ the interfering activity in the test-tube fluid had not dropped after incubation overnight of a chicken embryo membrane fragment with inactivated virus. For, when he added a second fresh membrane fragment to the same test-tube fluid after removal of the first fragment and incubated the tube again, he could measure about the same degree of viral interference in both membrane fragments. Isaacs thought that perhaps something like a new interfering activity had been generated. Lindenmann suggested to him the possibility that the observed effect could very well be due to a change in $\mathrm{pH}$ or to the absence of a nutrient in the test-tube. Isaacs, however, was struck by the idea that, somehow, new interfering activity had been produced, although he agreed with Lindenmann that the data present did not provide more than a dubious hint of this. As a joke, Lindenmann gave Isaacs' mysterious interfering activity the name of "interferon". 29

Isaacs' notebook has an entry for 6 November 1956, starting with the sentence: "In search of an interferon". ${ }^{30}$ These words marked the decision to change course and test Isaacs' assumption that a new interfering activity had been generated during their experiment. From that day on, they worked long hours tinkering with membranes, viruses and test-tubes in order to reproduce and amplify the observed effect. In the course of this process, Isaacs' assumption that new interfering activity had been generated in the test-tube was substantiated by further data, though more than once they were beset with doubts. There always remained the possibility that this "interferon" would turn out to be an artefact, a noise instead of a signal. Finally, after consultation with Christopher Andrewes, the head of the division of Bacteriology and Virus Research, and a Fellow of the Royal Society, they decided that the data were convincing enough for them to write up the results of the experiment and to submit them to the Proceedings of the Royal Society. In their two articles Isaacs and Lindenmann claimed they had found a new interference-inducing factor named "interferon". This was said to be released in a test-tube fluid following the incubation of inactivated influenza virus with a piece of chicken embryo membrane. The presence of interferon in the fluid could be recognized by its ability to induce an inhibitory effect upon the growth of a number of different viruses in fresh membrane fragments. ${ }^{31}$

In close collaboration with Lindenmann and the chemist Derick Burke, Isaacs continued research on this "product of influenza viral interference" or "interference inducing factor",

${ }^{26}$ See note 23 above.

27 Lindenmann, interview, see note 15 above.

${ }^{28}$ In the early fifties, Isaacs had learned from the interference experiments he had carried out in chicken eggs, that the interfering activity of a batch of inactivated influenza virus decreased with time.

${ }^{29}$ See note 25 above.

30 Isaacs, op. cit., note 17 above, 6 November 1956.

${ }^{31}$ See Alick Isaacs and Jean Lindenmann, 'Virus interference: I. The interferon', Proc. R. Soc., 1957, 147: 258-67; and A. Isaacs, J. Lindenmann and R. C. Valentine, 'Virus interference: II. Some properties of interferon', Proc. $R$. Soc., 1957, 147: 268-73. 


\section{Toine Pieters}

"interferon". By June 1957 they had shown that it was possible to prepare interferon in bulk, that it was conceivably a protein, and that it interfered with the growth of virus in the test-tube (in vitro) as well as in laboratory rabbits (in vivo). The latter deserves particular notice. In 1954 Isaacs had observed that if he injected rabbits intradermally with inactivated influenza virus, it interfered locally with a subsequent vaccinia virus infection. When a few years later a fluid, which was believed to contain interferon, appeared to interfere with the growth of vaccinia virus in a test-tube, Isaacs almost immediately tried out its effect on the animal model he had used before. Like the inactivated influenza virus earlier, it showed an inhibitory effect on the growth of vaccinia virus in the rabbit skin. $^{32}$

Apart from a private demonstration of interferon's workings at Isaacs' laboratory for officials of the MRC, interferon's first official appearance was at a meeting of the Swiss Society of Microbiology at the end of June 1957. On that occasion, Lindenmann, who had returned to Switzerland, presented a paper on interferon. However, his claim to have found a product of the viral interference reaction which could induce an inhibitory effect upon the growth of live virus in a test-tube did not make much sense to most of the scientists present. His audience generally considered viral interference to be an interviral inhibition phenomenon due to the competition between an interfering and a challenging virus for some key constituent within the cell. The idea of a viral interfering factor did not seem to fit into this internationally accepted concept of viral interference. For example, Prof. Hallauer, one of Switzerland's leading bacteriologists, objected that "as this [interferon] was utterly new and contrary to all he had read, it must be rubbish". ${ }^{33}$ The only people who were interested in Lindenmann's paper were a couple of scientists from the pharmaceutical company Ciba Geigy. They had just started research on interferon, after Ciba observers in London had learned about its discovery, and wanted Lindenmann to exchange information with them on this possible lead towards antiviral therapy. So, in a letter to Isaacs, Lindenmann asked whether he would be against exchanging information with Ciba researchers. ${ }^{34}$ Isaacs' reply was quite explicit: "I think it is a very bad idea to show our manuscript to anyone in a commerical firm. I would be very much against your doing so in future." ${ }^{35}$ In a subsequent letter he added:

In this country we are all very sensitive about the fact that penicillin is a British discovery, but that we have to pay royalties to American commercial firms for every gram of penicillin we use. I am not suggesting that interferon is in the same class as penicillin but on general grounds I don't think it is a good thing to deal with commerical firms. It is much better that they should wait until our information is published and then they can compete on even terms. ${ }^{36}$

\footnotetext{
32 See the annual report from the bacteriology and virus research group of the NIMR, 10, 1956/57, held at the NIMR library; J. Lindenmann, D. C. Burke, and A. Isaacs, 'Studies on the production, mode of action and properties of interferon', Br. J. Exp. Path., 1957, 38: 551-62; and Derick Burke, 'Early days with interferon', $J$. Interferon Res., 1987, 7: 441-2.

${ }^{3.3}$ Jean Lindenmann to Alick Isaacs, letter dated 28 June 1957, Jean Lindenmann correspondence, personal archives.

34 Ibid.

35 Alick Isaacs to Jean Lindemann, letter dated 1 July 1957, Jean Lindenmann correspondence, personal archives.

${ }^{36}$ Alick Isaacs to Jean Lindenmann, letter dated 7 July 1957, Jean Lindenmann correspondence, personal archives.
} 


\section{Interferon and its first clinical trial}

As before, there was a tendency amongst academic workers to view collaborative research with an industrial firm as an intrusion upon their scientific work. ${ }^{37}$ In addition, Isaacs was reflecting a general feeling amongst government and academic workers that, because of an inability to control the patents, penicillin had been given free to commercial drug houses and, in particular, American commercial firms. To avoid that situation recurring, most workers proceeded with caution in the case of new findings until the results had been published or patents had been filed. ${ }^{38}$

Ciba had to wait until October before the first two articles on interferon were published in the Proceedings of the Royal Society. Initially, these publications aroused only minor interest. Like their Swiss colleagues, most virus researchers in Britain and America were sceptical about the validity of the findings. They considered the idea of a viral interfering factor to be at odds with the established view on viral interference as mediated by virus particles. Moreover, those who overcame their initial doubts and tried to repeat Isaacs' and Lindenmann's experiments in other laboratories, found them difficult to replicate. Interferon became nicknamed "misinterpreton". 39 Among the small group of "believers", people who thought of interferon as more than some doubtful laboratory artefact, was the science correspondent of the Daily Express, who phoned Isaacs with a request for additional information. Although Isaacs refused this, an article was published in the Daily Express on the isolation of an antiviral substance named "interferon". "Following the article, the pharmaceutical companies Glaxo and Benger Laboratories wrote to the MRC, urging for a change of name of Isaacs' substance. Since both had got Registered Trade Marks for products with names similar to interferon, they anticipated difficulties if it were to be developed as a drug in the future. ${ }^{41}$ However, far from leading to a change of name, the article and letters led the MRC (who were quite "penicillin sensitive") to consider more urgently the patentability of Isaacs' discovery in order to protect the Council's interest in his work. ${ }^{42}$ The MRC first consulted their patent adviser at the National Research Development Corporation (NRDC) to see whether or not the subject-matter was patentable, with the result that, in May 1958, applications were made for patents in the United States, Canada and Germany. Unfortunately, it turned out to be impossible to obtain a British patent because more than six months had elapsed since the first public

\footnotetext{
${ }^{37}$ According to a 1941 article on pharmaceutical research there was a "tendency amongst academic workers to view with apprehension whole-hearted alliance with the research of any one firm", see, J. Liebenau, 'The British success with penicillin', Soc. Stud. Sci., 1987, 17: 69-86, p. 72.

${ }^{38}$ As a result of the British "failure" to exploit penicillin, the National Research Development Corporation (NRDC) was set up under the British Industries Act of 1948 to secure the development of inventions resulting from public research and if necessary to obtain patents for these inventions, see L. G. Matthews, History of pharmacy in Britain, London, E. \& S. Livingstone, 1962, pp. 330-3.

${ }^{34}$ Derick Burke, interview, Norwich, 14 May 1990, Norman Finter, interview, Beckenham, 25 May 1990, and David Tyrrell, interview, see note 18 above.

${ }^{40}$ Alick Isaacs to Jean Lindenmann, letter 23 October 1957, Jean Lindenmann correspondence, personal archives.

41 Glaxo to MRC, letter dated I November 1957, MRC Archives, File No. A814/17; Benger Laboratories to MRC, letter dated 28 November 1957, MRC Archives, File No. A814/17.

${ }^{42}$ MRC to Sir Charles Harrington, letters dated 6, 29 November, 5 December 1957, MRC Archives, File No. A814/17; Sir Charles Harrington to MRC, letters dated 13 November, 7, 10 December 1957, MRC Archives, File No. A814/17.
} 


\section{Toine Pieters}

report. ${ }^{43}$ Despite the patent applications and further articles in the Lancet and British Medical Journal, public interest in interferon was slow to develop. ${ }^{44}$ Interferon began to be known to the public after Isaacs and Burke had given a public demonstration of its effects at the Annual Conversazione of the Royal Society, 15 May 1958. The catalogue of the exhibits to be seen at the Royal Society, contained the following description:

\section{INTERFERON: AN INHIBITOR OF VIRUS GROWTH}

It has been known for many years that one virus may interfere with the growth of a second. Recently it was found that this interference is mediated through a substance which has been named 'interferon'. Active preparations of interferon can be easily produced by the litre without special equipment, and the activity can be readily concentrated. Such preparations are potent inhibitors of the growth of influenza and related viruses in vitro, and preparations which have been concentrated 10-fold inhibit the growth of vaccinia virus on the chick chorioallantoic membrane or in the rabbit skin. ${ }^{45}$

According to a correspondent of the Daily Telegraph a Fellow of the Royal Society had said at a press preview: "I find enormous excitement in the promise of interferon". ${ }^{46} \mathrm{Next}$ day the Daily Telegraph, among other newspapers, reported the discovery of a substance named interferon which might one day play an important part in the fight against viruses. Isaacs was even asked to repeat the demonstration on television, in a future programme of 'Eye on research'. ${ }^{47}$ The sudden press coverage of interferon as a potential antiviral therapeutic did not go unnoticed. Shortly afterwards, the MRC received a letter from the American pharmaceutical company Johnson \& Johnson, which had noted the publicity surrounding interferon in the UK and was most interested in receiving additional information on a possible new approach to human viral therapy. ${ }^{48}$ At the same time, the MRC was approached by a Glaxo executive about the patent position on interferon. Together with the American request for research information, ${ }^{49}$ this provided an important incentive for the MRC to consult the director of the NIMR, Sir Charles Harrington, with regard to further action on interferon. Harrington was said to welcome Glaxo's cooperation if it took the form of supplying interferon in large amounts. Further, he agreed with the MRC that, together with Glaxo, other pharmaceutical firms should be invited to co-operate through the Association of British Pharmaceutical Manufacturers (ABPM). ${ }^{50}$

\footnotetext{
${ }^{4.3}$ NRDC to MRC, letter dated 24 June 1958: “. . . applications covering the interferon invention have been filed in Germany under No. J14535 on March 11, 1958, in Canada under No. 750330 on April 28, 1958 and in the U.S.A. under No. 734106 on May 9, 1958", MRC Archives, File No. A813/104; Elkington and Fife, consulting chemists and chartered patent agents, to the MRC, letter dated 20 December 1957, MRC Archives, File No. A813/104.

${ }^{44}$ See editorials, 'A lead towards virus chemotherapy?', Lancet, 1957, i: 931-2; and 'Interferon', Br med. J., 1957, i: 1102 .

45 See the invitation to the Annual Conversazione of the Royal Society on 15 May 1958, The Annals of the Royal Society, 1958, I, p. 10.

th See newspaper article, “"Interferon” may aid fight against flu', Daily Telegraph, 16 May 1958.

${ }^{47}$ Alick Isaacs to Jean Lindenmann, letter dated 5 June 1958, Jean Lindenmann Correspondence, personal archives.

${ }^{48}$ The American pharmaceutical company Johnson \& Johnson to the MRC and vice versa, letters dated 16, 25 June 1958, MRC Archives, File No. A813/104.

${ }^{49} \mathrm{~A}$ similar informal request had been made by the American drug firm Merck \& Co. The latter approached Isaacs after he had presented a paper on interferon in New York, March 1958. Alick Isaacs to Jean Lindenmann, letters dated 19 March, 13 May 1958, Jean Lindenmann Correspondence, personal archives.

50) Internal note MRC, dated 4 November 1958, MRC Archives, File No. A813/104.
} 


\section{Interferon and its first clinical trial}

Obviously the MRC and the NIMR had become interested in developing and testing interferon as a drug, but realized that they had not enough resources for the production of sufficient quantities. Foreign interest in interferon speeded things up and convinced MRC and NIMR workers that seeking collaboration with a British commercial firm would serve the common interest. ${ }^{51}$ The missed opportunity in the UK to develop penicillin was still fresh in everybody's memory. If interferon were to prove to be the new "antiviral penicillin", the opportunity should not be lost to develop it in Britain. ${ }^{52}$ British drug firms should therefore be first to collaborate on interferon.

On 22 April 1959 at the NIMR, the representatives of most British drug companies were informed about the current state of affairs concerning interferon. Sir Charles Harrington opened the meeting by pointing out American interest in its development and the MRC's preference to seek collaboration with British firms first. Subsequently, both technical and patent matters were discussed in the light of the possible therapeutic value of interferon. ${ }^{53}$ Alick Isaacs was present to assist Harrington in answering technical questions, while a patent expert from the NRDC helped to clarify the patent position on interferon. The fact that the information available was considered insufficient by the American patent examiner was played down as a mere technicality. Because of lack of evidence on the drug's utility, the examiner had decided that the patent application for interferon as an antiviral agent had to be rejected until further research results could be made available. ${ }^{54}$

Until then drug companies had been very successful in developing antibiotics, such as penicillin, against a broad range of bacterial diseases. However, people were still waiting for the first effective antiviral agent to leave the research laboratories. Apart from vaccines, virtually no virus therapy was available. Thus the idea that Isaacs had possibly found a broad spectrum antiviral agent that might be fit for future use in man, was appealing. ${ }^{55}$ In the weeks following the meeting, Burroughs Wellcome (Wellcome), Glaxo Laboratories (Glaxo) and Imperial Chemical Industries-Pharmaceuticals (ICI) informed the MRC of their willingness to co-operate on a considerable scale. ${ }^{56} \mathrm{~A}$ further meeting was required to convince the MRC that each of the three drug firms would do their fair share of the work in the collaboration. All three companies stated that there was no limit to the research effort they were prepared to make. More significant was the fact that Glaxo's representative, Sir Harry Jephcott, announced that Wellcome and Glaxo were prepared to act as one, hoping thereby to exclude ICI from collaboration with the MRC. ${ }^{57}$ The matter was settled at an informal meeting a few days later when the MRC made it clear to Jephcott that ICI could not be arbitrarily excluded if the company wished to participate. ${ }^{58}$ Although I do not know what

\footnotetext{
51 In the case of penicillin the image of international competition helped British academic workers to overcome their initial distrust towards commercial drug firms. It convinced them that collaboration with British commercial firms would serve the public interest: see, Liebenau, op. cit., note 37 above, p. 75.

52 Interviews with Burke, Finter, Tyrrell, see notes 18 and 39 above.

${ }^{53}$ Minutes of a meeting to discuss collaboration in a programme of work on interferon, held at the NIMR, 10 April 1959, MRC Archives, File No. S788/1.

${ }^{54}$ Elkington and Fife, consulting chemists and chartered patent agents, to Alick Isaacs, letter dated 9 March 1959, MRC Archives, File No. A813/104.

5s David Wilson, Penicillin in perspective, London, Faber \& Faber, 1976.

56 The pharmaceutical companies Wellcome, Glaxo and ICI to the MRC and vice versa, letters dated May 1959, MRC Archives, File No. S788/1.

${ }^{57}$ Minutes of a meeting to discuss collaboration in a programme of work on interferon, held at the NIMR, 2 June 1959, MRC Archives, File No. S788/1.

${ }^{58}$ Internal note MRC, dated 5 June 1959, MRC Archives, File No. S788/1.
} 


\section{Toine Pieters}

made Glaxo and Wellcome act in this way, a reason might be that both had had dubious experiences with ICI as a collaborator on penicillin. During the Second World War a consortium of British pharmaceutical companies (including Wellcome, Glaxo and ICI), incorporated as the Therapeutic Research Corporation (TRC), had collaborated on a penicillin development programme. However, soon after the war had ended, ICI had prematurely pulled out of the penicillin programme. ${ }^{59}$

Yet another meeting with all parties (NIMR, MRC, NRDC, Glaxo, ICI and Wellcome) was held on 3 July to settle the outlines of an agreement for a collaborative programme of further work on interferon. Since the MRC had not taken part in the TRC during the war and had no experience with a peacetime model for collaboration with the drug industry either, they had entrusted the NRDC with the task of making proposals for such an agreement. At the joint meeting, the NRDC proposed to set up an executive body to hold property, grant licences, and administer the arrangement between all the parties involved. They also suggested that the NRDC's patent holdings corporation, which had been founded in 1952 with the aim of carrying out future collaboration between, for instance, the MRC and industry, should be used for this purpose. In addition they proposed to set up a scientific committee, which would come under the executive body and provide a platform for the exchange of technical information and know-how. Following initial discussions of these proposals between the MRC, the NRDC and the three drug firms, it was agreed that an executive body should be set up and that the NRDC's patent holdings corporation would serve this purpose. ${ }^{60}$ In addition they agreed on a scientific committee to consist of research workers from the industrial firms and the MRC under the chairmanship of Isaacs. This committee was to be responsible for advising the executive body on the scientific aspects of further work on interferon. ${ }^{61}$ Work on the drug was provisionally defined as "work on a viral interfering substance produced by the action of partially-inactivated virus on a susceptible tissue". ${ }^{2}$

While negotiations on the clauses in the Collaboration Agreement were still in progress, ${ }^{63}$ the scientific committee started discussing a programme of research.

\section{LOOKING BEHIND THE SCENES}

In September 1959, under the vigorous leadership of Isaacs, ${ }^{64}$ the scientific committee started to review and evaluate recent work on interferon. The following four major research

\footnotetext{
${ }^{59}$ Liebenau, op. cit., note 37 above, p. 83.

6) The executive body would be formalized in a GNRD Patent Holdings Ltd with a board made up of representatives of each of the collaborating firms and the NRDC, under an independent scientific chairman.

${ }^{61}$ Minutes of a meeting to discuss collaboration in a programme of work on interferon, held at the NIMR, 3 July, 1959, MRC Archives, File No. A812/5/1.

62 Proposed agreement with the NRDC on collaboration with some pharmaceutical firms, dated 10 July, 1959 , MRC Archives File No. A812/5/1.

${ }^{6.3}$ One of the major obstacles in the negotiations was the formulation of a clause on the publication of research results. It took until April 1961 to reach an agreement.

${ }^{6}$ Isaacs had suffered a severe bout of depression in the winter of 1958-59 and had only recently resumed all his duties at the World Influenza Centre (NIMR). After his return to work he is said to have changed dramatically in nature. From an open-minded scientist and skilful experimenter he seemed to have changed to a more speculative researcher, who was less interested in doing meticulous experiments and who vigorously pursued his own ideas regarding interferon. Andrewes, op. cit., note 14 above, p. 215 ; Burke, interview, see note 39 above, and Tyrrell, see note 18 above.
} 


\section{Interferon and its first clinical trial}

problems were singled out. ${ }^{65}$ First, MRC's research workers had recently observed a species-specific effect of interferon both in vitro and in vivo. Interferon prepared in chick tissues appeared to have a much higher antiviral activity when tested in vitro in chick cells than it did in calf cells. Similarly, chick interferon was found to have a far less protective effect against vaccinia virus than rabbit interferon when tested in vivo in rabbits. Despite the fact that this species-specific effect did not seem to be absolute, it could have far-reaching consequences for future research, if it were to be substantiated by further experiments, since, experiments on the virus-protective effect of interferon in animals, and maybe later in humans, would require samples of interferon that had been produced in cells of the same or a related species. ${ }^{66}$ Second, the measurement of the antiviral activity, or potency, of interferon preparations came up for discussion. Apart from assessing different assay techniques (biological activity tests), the committee discussed the problem of the comparability of assay data. The antiviral activity of the same interferon preparation had been shown to differ widely depending on the laboratory, the test method, or the scientist involved. It was agreed that, in order to facilitate comparative measurements of activity in the collaborating laboratories, each laboratory would put aside some of its interferon to be used as a standard preparation in the other laboratories. Third, a number of points were raised concerning the production of interferon. For instance, it was agreed that, in order to meet future demands for large amounts of the drug, more efficient production methods were required. Moreover, satisfactory methods for the purification and storage of interferon had yet to be developed. Finally, the difficulties of work with animals, in particular the translation of experiments from the test-tube to the laboratory animal were on the agenda. Attempts had been made to see if the protective effect of interferon against the influenza virus in the test-tube could also be demonstrated in mice. In this connection the dose and intranasal administration of interferon presented difficulties in vivo.

Having outlined these research requirements with the aim of developing interferon as an antiviral therapeutic agent in man and animals, the committee decided on a provisional programme for further work. ${ }^{67}$ This focused on the development of methods for the large-scale production and purification of interferon. However, in the short term it was felt essential to examine thoroughly the question of whether or not interferon was speciesspecific. Thus, each laboratory would concentrate on preparing interferon from cells of one species and measure its antiviral activity in cells from other species.

The provisional status of the research programme in the scientific committee contrasted with the way in which a press statement on the collaboration, issued a little later, described future work on interferon:

The stage has only recently been reached when the necessary development work that must precede therapeutic trial could be undertaken. ${ }^{68}$ [The italics are mine]

\footnotetext{
${ }^{65}$ Minutes of the first and second meeting of the Scientific Committee on interferon, 3, 9 September, 1959, MRC Archives File No. S788/2/1.

G6 A. Isaacs and M. A. Westwood, 'Inhibition by interferon of the growth of vaccinia virus in the rabbit skin', Lancet, 1959, i: 324-5; D. A. J. Tyrrell, 'Interferon produced by cultures of calf kidney cells', Nature, 1959, 184: 452-3.

${ }^{67}$ See MRC to Harrington, note 42 above.

${ }^{68}$ NIMR to MRC and vice versa, letters on the drafts of a press statement about the interferon collaboration and its goals, dated 13, 17 November, 15, 31 December 1959, MRC Archives, File No. S788/1.
} 


\section{Toine Pieters}

The necessary work was said to include both pilot scale production of interferon and studies of its effect on experimental virus infections of animals. The notion of uncertainty had been erased from the statement, thereby presenting the work as a rule-bound enterprise which was to follow a well-known and necessary path for testing potential therapeutic compounds. This is not to say that the work in the scientific committee was not "necessary development work", but that its nature was different. It was beset with uncertainties and was far less rule-bound than the press statement leads one to suspect. Until the spring of 1960 , research on interferon was carried out, more or less, along the lines of the provisional programme. The MRC's researchers mainly worked on the development of a purification method, the problem of the species-specificity, and the mechanism of action. Researchers from the collaborating firms focused on the production of interferon in cells of different species. ${ }^{69}$

In the meantime, the definition of the term "interferon" was continuously open to changes due to negotiations between the various interest groups, as the following two examples show. Thanks to Isaacs' continuous attempts to bring interferon to the notice of the international scientific community and his willingness to demonstrate interferon's workings to visiting researchers, as well as to his international reputation as an influenza virus expert, a growing number of researchers outside the UK became interested and started work on interferon. While Isaacs was in the process of convincing scientists outside the local context of the NIMR about the "fact status" of interferon, he was told that the American virologists John Enders and Monto Ho, and Robert Wagner had claimed to have found substances like interferon. These substances had been given names such as "Virus Inhibitory Factor" (VIF) and "Interferon B". ${ }^{70}$ In one of his letters to Lindenmann, who had also heard about the American situation and feared confusion in the field, Isaacs indicated that although they could not stop people from using different names for these substances, they might prevent this from happening in the future by giving a fairly broad description of interferon. He therefore proposed to use the following definition of interferon in a paper to be presented at the 'Perspectives of Virology' meeting in New York in January 1960:

a protein, slightly smaller than antibody globulin, produced by cells of different animal species following inoculation with inactivated or live virus of many different kinds and capable of inhibiting intracellularly the growth of a variety of viruses in cells of the same animal species, in doses which are not obviously toxic for cells. ${ }^{71}$

"I do not think, however, that it would be easy for us to be dogmatic in saying that a substance with these properties was interferon. It is usually much better to let someone go his own course and see what happens." ${ }^{, 72}$ Isaacs' strategy appeared to be successful,

\footnotetext{
${ }^{69}$ Minutes of the 3rd and 4th meeting of the Scientific Committee on interferon, dated 26 October, 26 November 1959, MRC Archives, File No. S788/2/1.

${ }^{70} \mathrm{M}$. Ho and J. F. Enders, 'An inhibitor of viral activity appearing in infected cell cultures', Proc. Natl. Acad. Sci., 1959, 45: 385-6; Alick Isaacs to Jean Lindenmann, letter dated 4 December 1959, Jean Lindenmann Correspondence, personal archives.

${ }^{71}$ Isaacs to Lindenmann, letter dated 4 December, 1959, see note 70 above.

72 Ibid.
} 
because at the 'Perspectives of Virology' meeting in 1961 it was agreed that the name interferon should be adopted for antiviral factors with the same characteristics as VIF. ${ }^{73}$

About the same time in Britain in one of the drafts of the collaboration agreement, "interferon" was described as,

any substance (other than antibodies) which is produced by the interaction of a virus and a living animal tissue and which is able to prevent, diminish or modify the multiplication of active viruses in living animal cells. ${ }^{74}$

This definition, which is formulated in broader terms than the former, evolved from discussions on the terms of a draft agreement relating to interferon between the participating parties in the collaboration. The fact that interferon did not denote a clearly characterized substance was a problem and it was agreed that a satisfactory definition should serve the purpose of both limiting the field of collaboration and of covering, under the agreement, as many natural virus-induced substances with antiviral properties as possible. ${ }^{75}$ It appeared to be rather difficult to find an acceptable definition which would be at the same time narrow enough and broad enough to satisfy both scientific and patent interests. The moment this definition made its appearance in the draft agreement it was immediately called into question. The NIMR research workers had just claimed to have found natural virus inhibitors which were different from interferon in that they shared serological characters with the virus responsible for their production. In order to prevent these newly discovered substances from being included in the field of collaboration on interferon, the NIMR urged for the following change in the wording of interferon's definition:

any substance (other than antibodies) which is produced by the interaction of a virus and a living animal tissue and which, whilst it lacks the serological properties of the virus, is able to prevent, diminish or modify the multiplication of active viruses in living animal cells. $^{76}$

Thus, not only was the definition of the term "interferon" continuously affected by changes due to negotiations between the various interest groups, but it was also highly dependent upon the context in which it was handled. Modalities which widened or narrowed the definition were added and dropped on an ad hoc basis. ${ }^{77}$

At a meeting of the scientific committee in April 1960, after eight months of research, the provisional research agenda was changed radically. ${ }^{78}$ During this meeting, research

\footnotetext{
${ }^{73}$ Monto Ho, 'An early interferon: "Viral inhibitory substance", J. Interferon Res., 1987, 7: 455-8, p. 456.

${ }^{74} \mathrm{MRC}$ to NIMR and vice versa, letters with comments on the drafts of an interferon agreement, dated 23, 31 March 1960. MRC Archives, File No. A812/5/1.

${ }_{75}$ Minutes of a meeting to discuss the draft Agreement prepared by the NRDC between Glaxo Laboratories Ltd., The Wellcome Foundation Ltd., Imperial Chemical Industries Ltd., the National Research Development Corporation and GNRD Patent Holdings Ltd. relating to collaboration on interferon, held at The Wellcome Building, Euston Road, on 27 January 1960, MRC Archives, File No. A812/5/1.

${ }^{76}$ MRC to NIMR and vice versa, letter with comments on the drafts of an interferon agreement, dated 23, 31 March 1960, MRC Archives, File No. A812/5/1.

${ }^{77}$ Latour and Woolgar have thoroughly examined the adding and dropping of modalities in scientific statements: see, Latour and Woolgar, op. cit., note 9 above.

${ }_{78}$ Minutes of the 6th meeting of the Scientific Committee on interferon, dated 6 April 1960, MRC Archives File No. 788/2/1.
} 


\section{Toine Pieters}

workers from the MRC reported the following two research results. First, when testing the specificity of interferon prepared in a variety of animal tissues, monkey interferon showed activity against a range of human and simian cells. In particular, the observation that monkey interferon appeared to be active against a number of respiratory viruses in human tissue-cultures aroused interest. It was agreed that, although extrapolation from individual tissues to the complete organism was hazardous, monkey interferon might be fit for future use in man. Moreover Wellcome's and Glaxo's experience with the production of poliomyelitis vaccine in large-scale cultures of monkey kidney cells was thought to be helpful in overcoming problems in the production and safety of monkey interferon. Second, the purification work on interferon had reportedly resulted in a pure product.

The prospect of the production of sufficient quantities of pure monkey interferon had a profound impact on the planning of further work on interferon by the scientific committee. Immediately four suggestions were made for future experiments with purified interferon in monkeys and humans: ${ }^{79}$

1) To test the protective effect against measles infection in volunteers. Since the MRC was in the process of assessing the effects of attenuated measles vaccine, facilities to test interferon's effect against measles would be available. However, it was remarked that measles is a systemic infection and therefore a measles trial would require considerable amounts of interferon. (This suggestion was made despite the fact that interferon's effect on measles had not yet been tested in vitro or in vivo.)

2) To test the protective effect of interferon on vaccination against smallpox in volunteers. There would be enough recruits available who had not yet been vaccinated and were willing to participate in a trial. Moreover, as a local infection it would need much less interferon than a systemic infection. (In the previous paragraph I pointed out that interferon appeared to have an inhibitory effect in the test-tube and on the skin of laboratory rabbits. Obviously, this experiment would be a translation of subsequent experiments in vitro and in vivo.)

3) To test the protective effect of interferon on respiratory infections in volunteers. A major advantage of this trial was thought to be the fact that the MRC had an official site for common cold trials in the form of the Common Cold Unit in Salisbury. In addition, the common cold was a local infection which would require only small amounts of interferon. (As mentioned above, interferon had shown a protective effect against respiratory viruses in the test-tube and, as such, this experiment would be a translation of experiments in vitro. Experiments with respiratory infections in mice, however, had not so far been very successful.)

4) To test the protective effect of interferon on trachoma virus infection in monkeys. This was considered to be an excellent experiment to do first, as a final check before experiments on man, and, as a local infection, it would require only small amounts of interferon. At that moment trachoma virus, which caused local infections in the eye, had just been cultured at the NIMR, and the MRC was keen on finding a therapy against this virus disease. ${ }^{80}$ (Like the measles experiment, this proposal was made despite the fact the interferon's effect on trachoma had not been tested either in vitro or in vivo.)

\footnotetext{
${ }^{79}$ Ibid.

${ }^{80}$ Statement of a senior MRC official during the discussion following the presentation of this paper to the Twentieth Century Medical History Group, held at the Royal College of Physicians, 11 February 1992.
} 
The scientific committee seems to have been keen on having an early demonstration of interferon's effect on man. It was aware of the fact that the American patent examiner had rejected interferon's patent application on utility grounds, and that if it could be shown to have an effect on man, even in an experimental infection, this decision would certainly be reversed. In addition there was a feeling that it would help to keep people interested and maintain the necessary pressure, because the negotiations on the collaboration agreement were not finished yet. ${ }^{81}$ At the same time interferon was looked upon as natural material that had been shown to be incredibly non-toxic in cells and was therefore expected to be harmless to humans. ${ }^{82}$ Since the representatives of the firms did not think it possible to produce large amounts of interferon in the short term, the committee decided to plan collaborative experiments for vaccinia, the common cold and trachoma, which would require only limited amounts of interferon. ${ }^{83}$ In addition they agreed to carry out the trachoma experiment on monkeys first.

Thus the committee discussed the preliminary work that was required and the ways in which its members could be responsible for different parts of the projects. For instance, David Tyrrell suggested the respiratory virus experiment be carried out at the MRC's Common Cold Unit in Salisbury, but not without extensive preliminary toxicity tests, while Wellcome and Glaxo scientists expressed their willingness to start producing large batches of monkey interferon. All agreed that an early start had to be made with work on the large-scale production, purification and storage of monkey interferon.

One of the MRC's officials made the following comments on the minutes of this meeting:

Please see the minutes of the sixth meeting. This collaboration seems to be going very well. They have purified interferon and now think they have a pure product. They are also now considering experiments on volunteers. Isaacs thinks that these experiments may take place about autumn. ${ }^{84}$

However, Isaacs' prediction that the first experiments on volunteers would be performed in the autumn of 1961 did not come true. At the next meeting in June, Tyrrell informed the committee of an experiment with monkey interferon on volunteers that was being carried out at the Common Cold Unit. A couple of days earlier, Tyrrell and a fellow member of the committee had inoculated themselves intranasally with a small amount of monkey interferon they had prepared in their laboratory at Salisbury. The night before the meeting they had challenged themselves by the same route with Coe virus, a type of Coxsackie virus, which was known to cause colds in humans. In previous tests this virus had been shown to cause colds nine times out of ten. A few months later Tyrrell reported that although his colleague had not had a cold, he had had one, and that the virus had been isolated from nasal washings of them both. Further, the interferon had not produced

\footnotetext{
${ }^{81}$ The collaboration agreement was signed on 24 October 1960, Memorandum and Articles of Association of GNRD Patent Holdings Limited, MRC Archives File No. S788/6.

82 John Beale, interview, London, 24 May 1990; interviews with Burke, Finter and David Tyrrell, see notes 18 and 39 above.

${ }^{83}$ No reference was made in the records to the reason for dropping the measles proposal right away.

84 Internal note MRC, dated 24 April 1960. MRC Archives, File No. S788/2/1.
} 


\section{Toine Pieters}

side-effects. The members of the scientific committee therefore agreed that a formal trial using volunteers was workable. ${ }^{85}$

Despite this early small-scale experiment with committee members as guinea-pigs, Isaacs' timetable for the planned experiments turned out to be over-optimistic. Because of problems with scaling up production and purification techniques in Wellcome's and Glaxo's laboratories, it was April 1961 before the first small batch of interferon became available for initial safety and potency tests. ${ }^{86}$ The fact that the production of interferon took much longer and resulted in less than was anticipated put the collaboration within the scientific committee under strain for a while. Isaacs, in particular, was disappointed by the slow rate of progress. In a letter to the MRC he even spoke about "the feeling that the firms were dragging their feet". ${ }^{87}$ During one of the committee meetings he brought the matter up and proposed to speed up the process by distributing the research work more efficiently among the different laboratories. However, the other committee members did not share Isaacs' feelings, although they found it advisable to have a more frequent informal exchange of information. ${ }^{88}$ Meanwhile, the trachoma experiment had been cancelled. According to Isaacs, interferon might not be active against the trachoma agent and it would be best to concentrate on the vaccinia and common cold experiments. ${ }^{89}$ Since the vaccinia experiment seemed to require less preparatory time, it was chosen as the first test for interferon's activity in humans.

In Britain, at that time, there was no compulsory safety system for testing drugs, and no unified system of toxity tests for clinical trials which would provide a regulatory context for experiments with interferon on man. In addition there were no formal rules on how to carry out a clinical trial. ${ }^{90}$ So the committee started with general discussions about the nature of the safety tests that should precede the trial. They agreed that small numbers of volunteers should be used before any large-scale trial was performed and that exhaustive safety tests were needed, but there were differences of opinion about the exact nature of the tests. Should they apply the same test procedures which were being used in the production of vaccines, or should they design a new test protocol? For instance, one of the committee members argued that quarantined animals, which were being used to test the safety of the polio-vaccine during its production process, would greatly increase the

\footnotetext{
${ }^{85}$ Minutes of the 7th and 8th meeting of the Scientific Committee on interferon, dated 24 June, 10 October 1960, MRC Archives, File No. S788/2/1.

${ }^{86}$ Minutes of the 11 th meeting of the Scientific Committee on interferon, dated 19 April 1961, MRC Archives, File No. S788/2/1.

${ }^{87}$ Alick Isaacs to the MRC, letter dated 27 October 1961, MRC Archives, File No. S788/2/1.

${ }^{88}$ Minutes of the 12th and 13th meeting of the Scientific Committee on interferon, dated 5 June, 13 September 1961, MRC Archives, File No. S788/2/1.

${ }^{89}$ Minutes of the 9th meeting of the Scientific Committee on interferon, dated 5 December 1960, MRC Archives File No. S788/2/1.

${ }^{90}$ Since the start of the Health Service in 1948 there had been a committee under Lord Cohen which dealt with the effectiveness and safety of drugs, but it had almost no real power. The committee found that manufacturers discharged their responsibilities effectively "within the limits of contemporary knowledge of methods of testing". The first steps towards a central regulatory agency on drugs safety were taken after the Thalidomide case (1960-61) with the setting up of a Committee on Safety of Drugs (the Dunlop Committee) in June 1963. However the functions of this committee did not become compulsory until the Medicines Act of 1968. William Breckon, The drugmakers, Plymouth, The Bowering Press, 1972, pp. 121-41.
} 
expense of the project and that it was more important to pay attention to the safety of the final product. ${ }^{91}$ On the basis of these discussions, preliminary safety requirements were drafted for the production of interferon for clinical trials. ${ }^{92}$ In order to finalize a detailed test protocol, a special interferon safety test meeting was held with experts from the MRC's immunological products control laboratory in Hampstead, where a lot of knowledge and skill in testing the safety of vaccines had been accumulated over the years and it was thought that, as a biological product, interferon would profit from this pooled experience. The test protocol that resulted from the discussions with the experts at Hampstead required a series of in vitro and in vivo tests, during and after the production process, so as to exclude the possible presence of bacteria and viruses. The exclusion of viruses was regarded as particularly problematic, since small quantities of active virus might always be masked by the presence of interferon as a potent inhibitor of virus growth. It was agreed that the same methods should be applied as were being used in the production of vaccines, since no method of excluding viruses was known to be fool-proof. ${ }^{93}$

Finally, I should mention two major problems encountered during and after the vaccination experiment early in 1962. According to the safety protocol of the trial, the monkey interferon to be used in this experiment was to be subjected to a series of final toxicity tests which were also used on a routine basis in the production of vaccines. First, interferon had to be injected in mice and guinea-pigs. If no adverse effects were registered in the laboratory animals, it would be injected into the skin of the arms of members of the committee. If this test was also satisfactory the trial would proceed. ${ }^{94}$ In practice, the toxicity tests in mice went satisfactorily, but this was not the case for similar tests in guinea-pigs, which died within three to four days of an inoculation with interferon. Consequently, a debate arose within the committee over the safety of interferon. A Wellcome scientist pointed out that guinea-pigs were known to be highly susceptible to small amounts of penicillin, and that there might be enough penicillin in the interferon preparation to be fatal. Penicillin was present in the injections since it was used to prevent bacterial infection in the large-scale culture of monkey kidney cells in which the interferon was produced. After much discussion, it was ageed that both evidence in the literature and personal experience pointed to a singular sensitivity of guinea-pigs to penicillin, and it was decided to go ahead with the experiment. As a safety measure penicillin-sensitive volunteers were excluded from the vaccination trial. ${ }^{95}$

The second problem occurred after the trial. At a routine check of the research results from the participating laboratories, an MRC official came across oddities in the figures

\footnotetext{
${ }^{91}$ Minutes of the 7th meeting of the Scientific Committee on interferon, dated 24 June 1960, MRC Archives, File No. S788/2/1.

92 Minutes of the 10th meeting of the Scientific Committee, dated 16 February 1961, MRC Archives File No. S788/2/1;

${ }_{93}^{93}$ Minutes of the Interferon Safety Test Meeting, dated 22 February 1961, MRC Archives, File No. S788/2/1; Minutes of the 11 th meeting of the Scientific Committee on interferon, date 4 April 1961, MRC Archives, File No. S788/2/1.

${ }^{94}$ Minutes of the 12th, 13th and 14th meetings of the Scientific Committee on interferon, dated 5 June, 13 September, 20 October 1961, MRC Archives, File No. S788/2/1.

${ }_{95}$ Minutes of the 15th meeting of the Scientific Committee on interferon, dated 14 December 1961, MRC Archives File, No. S788/2/1.
} 


\section{Toine Pieters}

from the Wellcome laboratories. I do not know what made him find them or what they were, but there was a considerable difference between the data from the NIMR and Wellcome. At the NIMR 23 volunteers had been vaccinated against smallpox at two sites on one arm, where they had previously been inoculated with interferon and the control. There had been 17 volunteers with a lesion at the control site and no lesion (hence successfully protected) at the interferon site. On the other hand, at Wellcome 19 volunteers were tested, but only 8 cases were reported with a lesion at the control site and no lesion at the interferon site. ${ }^{96}$ At any rate, the official informed Isaacs, who, on closer examination of the research data, could not escape the impression that Wellcome had tampered with codes and numbers. Moreover, there had been a failure to blind the observer, since the observer and the vaccinator were the same person, and, furthermore, the observer also took part as a volunteer in the trial. In consultation with the scientific committee, Isaacs tried to cover up for Wellcome's research data in a draft of the research report. However, Dr Edwards, who had been responsible for the trial at Wellcome, discussed the matter with him and said that it would be better not to make any reference to the Wellcome data. Isaacs, in turn, contacted the MRC and asked for advice. The medical officer in charge at the MRC was not sure himself and told him to discuss the matter with Sir Charles Harrington. Subsequently, Harrington decided in consultation with the research director of Wellcome that its research figures should be deleted from the text of the report. ${ }^{97}$ In the meantime the original report had been submitted to the Lancet but was being held up until the matter had been settled. With the "delete decision" in mind it is surprising to see that in the final Lancet report three Wellcome volunteers can still be found (see Table 1). ${ }^{98}$

In spite of the excitement in the scientific committee about the outcome, the vaccinia trial had a negative impact on the interferon enterprise. The managing boards of the three companies were not at all convinced by the outcome, which they thought was rather trivial. Interferon had shown only a minor effect in a minor viral disease. Furthermore, it had cost a lot of money to perform the vaccinia trial. Apart from the high costs of producing only minute amounts of interferon from monkey kidney cells, the production process was bedevilled by many technical problems and there was no immediate prospect of an alternative source for human interferon. It was felt that interferon was not worth the effort that was being put into it. As a result, the commitment of the three companies to the interferon enterprise came under pressure. ${ }^{99}$

At about the same time, the scientific committee embarked on a second experiment with interferon on human volunteers. This time the committee chose to test the protective effect of interferon against the common cold. It was argued that if it were to show an effect against a frequent viral disease like the common cold then interest within the consortium would be restored. The trial did indeed have a great impact, because, when it became clear that no effect could be detected, the interest in interferon within Glaxo, ICI and Wellcome

\footnotetext{
${ }^{96}$ Minutes of the 16th meeting of the Scientific Committee on interferon, dated 22 February 1962, MRC Archives File, No. S788/2/2.

${ }_{97}$ Alick Isaacs to Derick Burke, letter dated 5 April 1962, Derick Burke Correspondence, Norwich, personal' archives.

${ }^{98}$ Internal Note MRC, dated 4 April 1962, MRC Archives File No. A813/127; Scientific Committee on Interferon, April 28, 1962. Effect of interferon on vaccination in volunteers, Lancet, 1962, i: 873-5, p. 874.

${ }^{99}$ Interviews with Beale, Burke, Finter and Tyrrell, see notes 18, 39 and 82 above.
} 


\section{Interferon and its first clinical trial}

Table 1: RESULTS OF INDIVIDUAL VACCINATIONS IN THE VACCINATION TRIAL

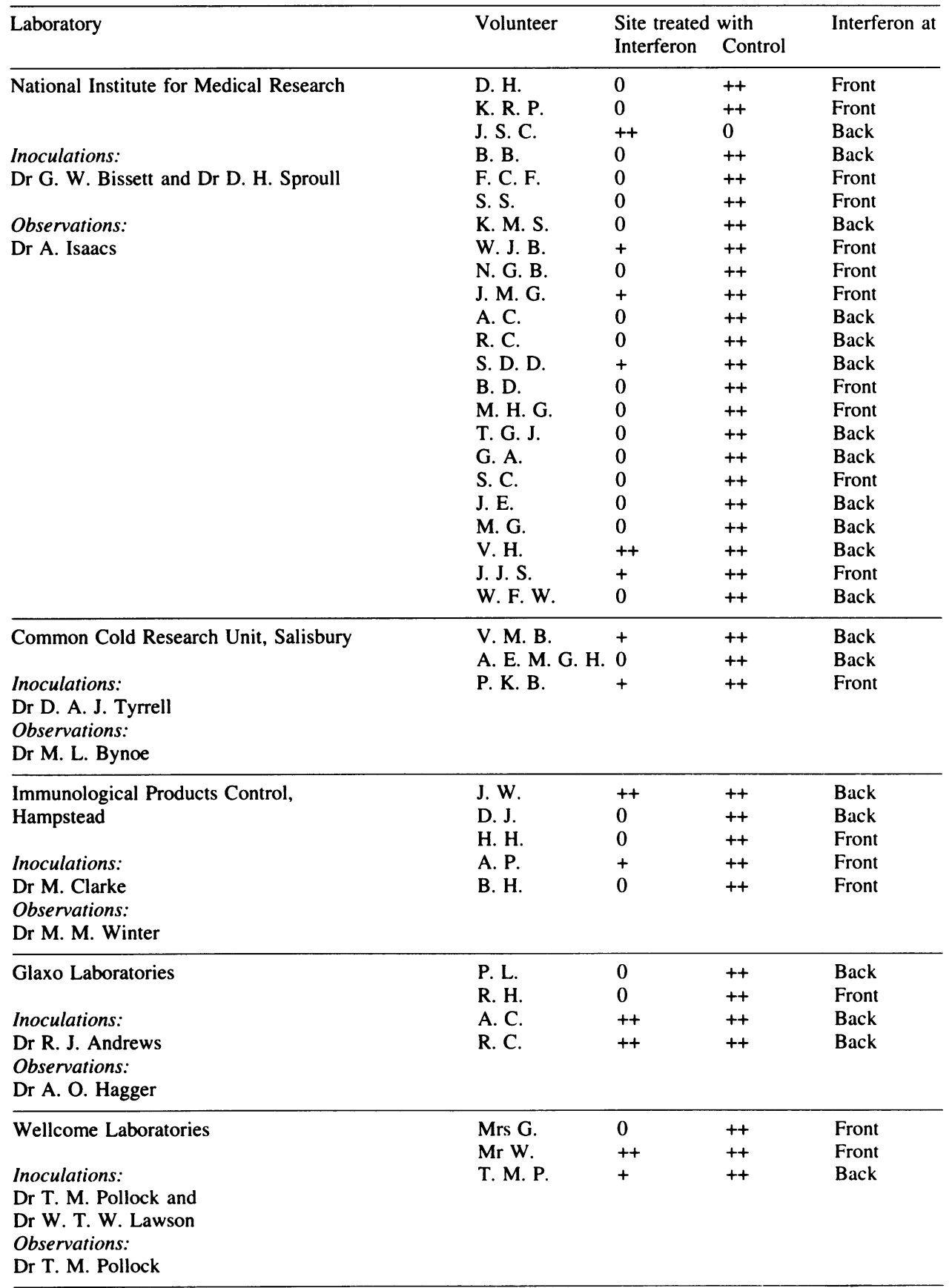

$++=$ Definite take

$+=$ Take, but distinctly smaller than the take at the other site

$0=$ No take 


\section{Toine Pieters}

plummeted. In spite of the fact that the scientific committee argued that the failure was probably due to the low dosage and the impurity of the preparation, interferon was regarded by the management as a clinically useless, undefined biological entity, which only showed an effect in the test-tube and for which no economical production method was available. Yet the collaboration continued, mainly because the companies felt, as they expressed in their memoranda, that they had an obligation to the government to do so. However, there was reluctance within the consortium to spend more money on the production of monkey interferon and to proceed with tests on humans. Confronted with a sharp decline in resources and the obvious lack in understanding of interferon's action, the committee shifted attention back to tests on animals and cell cultures. ${ }^{100}$

Even the best crystal-gazer could not have foreseen in 1965 that almost thirty years later interferon was being prescribed in hospitals all over the world against a number of viral diseases and, even more surprisingly, against a variety of cancers.

\section{CONCLUSIONS}

In retracing the origins of interferon, I have tried to retrieve some of the contingencies and uncertainties which were faced in and outside the laboratory regarding interferon. To begin with, I focused on the laboratory practice which was instrumental in shaping interferon's early profile as an interference-inducing factor, which was said to induce an inhibitory effect upon the growth of a number of viruses in the test-tube (in vitro) and against vaccinia virus in the rabbit skin (in vivo). We have seen how the virologists, Isaacs and Lindenmann, for some time unsuccessfully tinkered with an ad hoc brew of materials and techniques in order to test the hypothesis that in analogy with bacterial viruses (bacteriophages) during influenza virus infections, only the virus nucleic acid entered the host cell, while the virus coat remained outside the cell ("nucleic acid hypothesis"). The greater part of their experimental tools had either been employed in earlier experiments or circulated in the local context of the NIMR. Every new experiment meant a rearrangement of the experimental set-up and hence new uncertainties to the bench workers. For instance, by replacing the chicken egg with a novel in vitro system, it was uncertain whether virus-coated red blood cells still induced interference. Further, at the very moment Isaacs observed something unusual happening in the test-tube, an ad hoc judgment had to be made as to whether or not to pursue this artefact instead of further testing the "nucleic acid hypothesis". The words "in search of an interferon" in Isaacs' notebook marked the decision to change course and test Isaacs' assumption that new interfering activity had been generated in the test-tube. Another period of "tinkering" with membranes, viruses and test-tubes followed. In this process of fine tuning the experimental arrangement the presence of an interfering factor was readily substantiated by further data, though more than once Isaacs and Lindenmann were beset with doubts. There always remained the possibility that this "interferon" would turn out to be a noise instead of a signal.

Once interferon had acquired a rudimentary fact status within the NIMR, attempts were made to present the "new-born" to the outside world. Initially it got a cool reception from the scientific community, despite the publication of two articles on it in the Proceedings of the Royal Society. In general, the idea of a viral interfering factor was considered to be at

I(K) Ibid. 


\section{Interferon and its first clinical trial}

odds with the established view on viral interference as mediated by virus particles. Moreover, those who tried to repeat Isaacs' and Lindenmann's experiments in other laboratories had difficulty replicating them. However, the moment interferon was presented as an antiviral substance, a potential medical innovation, it gained momentum. By bridging the gap between laboratory and medical practice interferon gained more certainty. In particular the penicillin metaphor played a major role in this respect and was instrumental in mobilizing interest in interferon, principally in the UK.

The first reference to penicillin was made by Isaacs in response to a letter from Lindenmann, who asked for permission to exchange information on interferon with a commercial drug firm as a possible way towards antiviral therapy. As we saw, Isaacs fiercely opposed this request, thereby highlighting the sensitivity in Britain over the fact that penicillin, which was a British discovery, was developed by American commercial firms. In doing so Isaacs was reflecting a general feeling amongst government and academic workers that because of the inability to control the patents, penicillin had been given away gratis to commercial drug houses, and in particular American commercial firms. To avoid a recurrence of that situation, most workers proceeded with caution in the case of new findings, until the results had been published or patents had been filed. This "penicillin sensitivity" subsequently affected the MRC. The latter had been informed about the discovery of an antiviral substance at the NIMR early on, but no further steps were taken until the possibility to develop interferon as a drug suggested itself. It was immediately felt that, in order to protect the Council's interests, interferon should be patented. The MRC's interest increased even more when, after a public demonstration of interferon's effects at the Royal Society and the subsequent press coverage, commercial drug firms, in particular American companies, approached the Council with requests for information on interferon. If interferon proved to be the new "antiviral penicillin", the opportunity should not be lost to develop it as an antiviral drug in Britain. However, the MRC realized it lacked the resources and expertise for such an undertaking and decided that British drug firms should be the first to collaborate on interferon. Until then, drug companies had been successful in developing drugs against bacterial diseases. However the firms were still waiting for the first effective antiviral to leave the research laboratories. Thus, the idea that Isaacs had possibly found a kind of "magic bullet" against viruses was appealing. It is not surprising therefore that most British drug companies were present at a first meeting with the MRC, which was held to inform them about the state of affairs concerning interferon.

Ultimately Glaxo, ICI and Wellcome told the MRC of their willingness to co-operate on a considerable scale. Then Glaxo and Wellcome were prepared to act as one party in this work, thereby hoping to exclude ICI from collaboration with the MRC. A possible explanation for this could have been the unhappy experience of both companies with ICI as a collaborator on penicillin at the end of the Second World War. However, the MRC decided it could not arbitrarily exclude ICI. Since the MRC had not taken part in the TRC during the war and had no experience with a peacetime model for collaboration with the drug industry either, they entrusted the National Defence Research Corporation with the task of making proposals for a collaborative agreement with the three drug companies. In consultation with the firms it was decided to set up an executive body to hold property and 
administer the arrangement, and that a Patent Holdings Corporation would serve this purpose. Furthermore they agreed on a scientific committee to consist of research workers from all parties under the chairmanship of Isaacs, to advise the executive body on scientific matters. It was this scientific committee which was mainly responsible for the planning and realization of the Lancet trial.

Right from the start the research workers faced difficulties in communicating research results. Part of the problem was due to the initial distrust between industry and academic workers, but there was another reason. The antiviral activity or potency of one interferon preparation had been shown to differ widely depending on the laboratory, the test method and the scientist involved. In order to handle these variables and reduce the uncertainty regarding the exchange of research data, the committee agreed to set standards for interferon tests. ${ }^{101}$ In addition there were ambiguities in translating experiments from the test-tube to laboratory animals, or to humans. Apart from technical uncertainties (e.g., differences in dose and route of administration), the transition involved the more fundamental question of whether or not extrapolation from one organism to the other could be justified. This uncertainty regarding experimental transitions was handled in a rather pragmatic way. When scientists reported the observation that monkey interferon showed an activity against viruses in human cells in the test-tube, it was agreed that extrapolation from individual cells to the complete organism was hazardous. Yet it was decided to proceed with experiments in monkeys and humans. The factors involved in this decision have been shown to be manifold. For instance Glaxo and Wellcome workers had experience with the large-scale production of biological products (vaccines) in monkey cells and it was therefore thought that safety and production problems would be manageable. At the same time it was announced that the purification work on interferon, which was looked upon as a non-toxic natural material, had resulted in a pure product. In addition the patent examiner had rejected interferon's patent application on utility grounds and an effect in man would certainly help to reverse this decision. In the latter case the political uncertainty concerning interferon's patent position interfered with the uncertainty in laboratory practice.

With regard to the Lancet trial, the decision to do a first test with interferon on vaccination against smallpox in volunteers, was largely based on ad hoc criteria and judgments. ${ }^{102}$ Some of these concerned the amount of interferon needed in the trial, the preparatory time, again the patent situation, and the availability of test objects or facilities. This is not to say that the decision was unscientific. Ad hoc judgments and assumptions are part and parcel of science and technology, ${ }^{103}$ due to the contingencies and uncertainties that govern developmental practices. This is especially true for the planning of the vaccinia trial, since there was at that time no compulsory safety system in Britain for the testing of drugs and no unified system of toxity tests to allow for clinical trials which

\footnotetext{
${ }^{101}$ For an extensive account of the role of standardization in the development of biologicals, see, Nelly Oudshoorn, 'The making of the hormonal body', PhD thesis, Amsterdam, 1991.

${ }_{112}$ Brian Wynne pointed out the important role of ad hoc rules and judgements in developmental practices such as clinical trials in: B. Wynne, 'Unruly technology: Practical rules, impractical discourses and public understanding.' Social Studies of Science, 1988, 18: 147-67, p. 162.

${ }^{103}$ Feyerabend, Garfinkel and Lynch pointed out the central and essential role of ad hoc reasoning in scientific practices, see Michael Lynch, Art and artefact in laboratory science, London, Routledge \& Kegan Paul, 1985, pp. 134-5.
} 


\section{Interferon and its first clinical trial}

would provide a regulatory context for experiments with interferon on man. I have clearly shown that in order to cope with the uncertainties in the preparations for the trial, and during the trial itself, the scientific committee relied heavily on knowledge and skill derived, over the years, from testing biological products, in particular vaccines, both within the companies and the MRC.

My detour behind the scenes of a clinical trial clearly shows that in the future it would be better to start from the premise that, if anything is evident it is the lack of self-evidence in bio-medical experiments and experimental transitions. 